\title{
Effects of fire frequency on nutrient levels in soils of Aleppo pine forests in southern France
}

\author{
María Teresa Iglesias $(*)$
}

\begin{abstract}
Iglesias, M.T. Effects of fire frequency on nutrient levels in soils of Aleppo pine forests in southern France. Lazaroa 31: 147-152 (2010).

Fire is a dominant factor in the evolution and ecology of Mediterranean-type ecosystems. The effects of wildfires on the chemical properties of soils beneath the Aleppo pine forest, after recurrent and individual fires, have been studied. The burned area was located near Montpellier (south-eastern France) where the climate is Mediterranean. In the burned area 30 plots of soils (10 burned in July 1981; 10 burned in September 1996; and 10 burned in July 1981 and reburned in September 1996) were selected and sampled.

Ten soils were also sampled in an unburned part of the forest as control. All soils (burned and unburned) were sampled at 0-5 (layer 1) and 5-10 (layer 2) cm depth. The greatest differences were observed in soils burned in 1996 in comparison with the others; there were also increases of organic matter in the burned soils, as well as in total $\mathrm{N}$ and available $\mathrm{P}$, particularly in layer 2. Levels of Ca were slightly higher in burned than in control soils, but exchangeable $\mathrm{Mg}$ and $\mathrm{K}$ did not differ significantly. The $\mathrm{pH}$ values did not change after wildfires; but electrical conductivity decreased slightly in layer 1 of the burned soils. Values for exchangeable cations of burned soils were always similar to those in control soils.
\end{abstract}

Key words: Wildfire, soil chemical properties, Pinus halepensis, Mediterranean forest.

Resumen: Iglesias, M.T. Efectos del fuego sobre los niveles de nutrients de los suelos de pinares de Alepo en el sur de Francia. Lazaroa 31: 147-152 (2010).

El fuego juega un papel importante en la evolución de los ecosistemas Mediterráneos. En el presente trabajo se estudian los efectos de incendios repetidos en suelo bajo Pinus halepensis. La zona de estudio estaba situada en Montpellier (sureste de Francia) y el clima es mediterráneo. Se seleccionan y muestrearon 30 muestras de suelo (10 quemadas en 1981, 10 quemadas en 1996 y 10 quemadas en julio de 1981 y requemadas en septiembre de 1996). Diez suelos se muestrearon en una zona no quemada situada en la proximidad de la zona quemada.

Se muestrearon los primeros $5 \mathrm{~cm}$ del suelo (horizonte 1) y hasta $10 \mathrm{~cm}$ (horizonte 2). Las mayores diferencias se apreciaron en los suelos quemados en 1996, en comparación con los otros suelos. También se detectaron aumento del contenido de materia orgánica en el suelo quemado, así como $\mathrm{N}$ y P disponible en el horizonte 2. Los niveles de calcio también fueron mayores en los suelos quemados, que en el control, sin embargo no se observaron diferencias significativas en los valores de $\mathrm{Mg}$ y K. Los valores de $\mathrm{pH}$ no cambian después del paso del fuego y la conductividad eléctrica disminuye en el horizonte 1 de suelos quemados. Los cationes de cambio son similares a los del suelo control.

Palabras clave: incendio forestal, propiedades químicas, Pinus halepensis, bosque Mediterráneo

\section{INTRODUCTION}

The role of fire has been prominent in Mediterranean forest ecosystems for thousands of years, and wildfires induce changes in the nutrient con- tents and nutrient availability of soils. Fire plays two major roles in ecosystems, first in shaping plant community structure and composition, and second in the effect of phytomass burning on nutrient cycling. The direction, magnitude and depth

\footnotetext{
* Universidad de San Francisco de Vitoria. Ctra. Pozuelo-Majadahonda, km 1,800. Pozuelo de Alarcón (Madrid). E-mail: m.iglesias.prof@ufv.es
} 
of influence of these changes in soils depend on many factors, including maximum burn temperature, length of burn, fuel composition, soil texture, water content and the nutrient dynamics (WoODMANSEE \& WALLACH, 1981; JOHNSON \& al., 2005; DE MARCO \& al., 2005; MuRPHY \& al., 2006). KUTIEL \& SHAVIV (1989) found that an increase in the temperature of the soil from $250^{\circ} \mathrm{C}$ to $600^{\circ} \mathrm{C}$ was followed by a reduction of most of the available nutrients. KUTIEL \& NAVEH (1987a) also observed that there was a significant difference in soil nutrient levels measured after a wildfire in various patches that are dominated by different species.

The most significant changes in chemical properties of the surface soils are likely to result from the addition of ash and partially burned material (UleRY \& al., 1993; CERTINI 2005; MURPHY $\& a l ., 2006)$. When the vegetation and surface litter are burned, ash usually provides an increase in the $\mathrm{pH}$ of soil, as well as an increase in nutrients available to plants (ULERY \& al., 1995; DE MARCO \& al., 2004). The main changes in the characteristics of a soil occur more particularly in the upper layers $(0-5 \mathrm{~cm}$ and $5-10 \mathrm{~cm})$ of mineral soil. The magnitude of these effects depends on fuel mass related to the intensity of the fire, the pre-fire base saturation, the degree of ash convection from the site, and post-fire weather events (NEARY \& al., 1999).

The objective of the present research was to determine the possible effect of wildfire (recurrent or not, on the same site and community) on the chemical composition of a typical Mediterranean soil under an Aleppo pine (Pinus halepensis Mill.) forest.

\section{MATERIALS AND METHODS}

The study was carried out in hilly country 10 $\mathrm{km}$ north of Montpellier ( $3^{\circ} 50 \mathrm{E} ; 43^{\circ} 40 \mathrm{~N}$ ), in southern France. The mean elevation ranges between 120-130 m a.s.l. The climate is Mediterranean humid according to Emberger's classification. Mean annual rainfall is $850-950 \mathrm{~mm}$, with a summer drought (June to August) during which only $135 \mathrm{~mm}$ of rain fall. Mean annual temperature is about $13-14^{\circ} \mathrm{C}$. Bedrock consists of conglomera- tes and sandstones of lower Oligocene. The soil is classified as light brown rendzina (lithic xerorthent) highly calcareous and clayey; the characteristics for the 1-10 cm depth are: active $\mathrm{CaCO}_{3}$ : 2.7\%; texture (in \%): clay: 39.8, silt: 33.1, sand: 27.0 (unpublished personal data). Vegetation is an open conifer forest of Pinus halepensis Mill. about 50 years old, with an understorey dominated by Rosmarinus officinalis L, Cistus monspeliensis L, and Quercus coccifera L. One part (630 ha) of the forest was burned in July 1981, another part (25 ha) in September 1996, and a third part (50 ha) was burned twice during the fires of 1981 and again in 1996. In each fire all the trees were totally destroyed. Fortunately a large part of the area remained unburned and served as a control.

To determine the effect of one fire and recurring wildfires on soil physico-chemical properties, soil samples were collected, the same day, 9 months after the most recent fire in 4 different sites having similar characteristics (same aspect, same slope), but different fire recurrences. In each of the four types of sites, ten samples were collected at random at two depths: layer 1: 0-5 cm; layer 2: $5-10 \mathrm{~cm}$, as fire affects mainly the soil surface.

After removing large stones, the soil samples were air-dried and passed through a $2 \mathrm{~mm}$ mesh sieve; then they were stored in paper bags prior to analyses. All analyses were performed on each sample. Soil pH was measured at a 1:2.5 soil/water ratio, and at a $1: 2.5 \mathrm{soil} / \mathrm{KCl}$ ratio with a glass electrode. Electrical conductivity was measured in 1:5 soil/water ratio extract; extractable cations were determined after extraction with 1 $\mathrm{M}$ ammonium acetate at $\mathrm{pH}=8$.2. Calcium carbonate was measured by treating soil samples with $1 \mathrm{~N}$ perchloric acid under external heating, and tritation of the excess acid with $\mathrm{NaOH}$; organic matter by fire calcination. Total $\mathrm{N}$ content was measured using an automatic $\mathrm{CNH}$ analyser (LECO CNH-600); organic C by Walkley-Black wet digestion; and available $\mathrm{P}$ using the Watanabe \& Olsen's bicarbonate extraction method.

Differences between burned and unburned soils were tested using an analysis of variance (ANOVA) at 0.05 levels, with a least significance (LSD) pairwise comparison of means test between treatments (SPSS 15.0). 


\section{RESULTS AND DISCUSSION}

Results for layer 1 are reported in Tables 1 and 2; those for layer 2 are reported in Tables 3 and 4.

Significant difference was found between water $\mathrm{pH}$ values of burned and unburned soil at $0-5 \mathrm{~cm}$ (Table 1), in layer 2 there were no significant differences in $\mathrm{pH}$ (Table 3). Changes in $\mathrm{pH}$ with burning are very dependent on the amount and nature of the ash, the depth of sampling, time after fire and the time the ash has been in contact (liming effect of ash) with the mineral soil (KUTIEL \& al., 1990; UleRY \& al.,1995; HeRAS \& al.,1995; ÚBEDA \& al., 2004).

Electrical conductivity decreased, but not significantly for layer 1 and layer 2 respectively, to below the values of unburned soil. This could be due to precipitation reactions and leaching (KUTiEl \& Shaviv (1989), CERTINI (2005), MurPhy \& al. (2006); DLAPA \& al. (2008) explain that the enhancement of hydrophobicity can render the

Table 1

Mean values (standard error in parentheses) of $\mathrm{pH}$, electric conductivity (EC), $\% \mathrm{CaCO}_{3}, \%$ organic matter (OM), $\%$ total $\mathrm{N}$, and available $\mathrm{P}$ in layer 1 (0-5 cm depth) of the study soils.

\begin{tabular}{|c|c|c|c|c|c|c|}
\hline Fire frequency of soil samples & $\mathrm{pH} \mathrm{H}_{2} \mathrm{O}$ & E.C.dSm ${ }^{-1}$ & $\mathrm{CaCO}_{3} \%$ & O.M. \% & $\mathrm{N} \%$ & $\mathrm{P} \mathrm{mgkg}^{-1}$ \\
\hline Control (no fire) & 7.75 & 0.202 & 19.81 & 8.41 & 0.25 & 6.17 \\
\hline 1 fire 1981 & 8.00 & 0.117 & 24.93 & 6.24 & 0.22 & 5.92 \\
\hline 1 fire 1996 & 8.14 & 0.157 & 23.81 & 10.57 & 0.39 & 13.63 \\
\hline \multirow[t]{2}{*}{2 fires 1981/96 } & 8.04 & 0.139 & 28.00 & 9.75 & 0.35 & 19.42 \\
\hline & $*$ & NS & NS & $*$ & $*$ & $*$ \\
\hline
\end{tabular}

$\mathrm{NS}=$ not significant. $*=\mathrm{p}<0.05$

Table 2

Mean values (standard error in parentheses) of cation exchange capacity (CEC), exchangeable $\mathrm{Ca}, \mathrm{Mg}, \mathrm{K}$ and $\mathrm{Na}$ $\left(\mathrm{cmol} \mathrm{kg}^{-1}\right)$ in layer $1(0-5 \mathrm{~cm}$ depth) of the study soils.

\begin{tabular}{lccccc}
\hline Fire frequency of soil samples & $\mathrm{CEC} \mathrm{cmolkg-1}$ & $\mathrm{Ca} \mathrm{cmolkg}^{-1}$ & $\mathrm{Mg} \mathrm{cmolkg}^{-1}$ & $\mathrm{~K} \mathrm{cmolkg}^{-1}$ & $\mathrm{Na} \mathrm{cmolkg-1}^{-1}$ \\
\hline Control (no fire) & 20.94 & 22.85 & 1.39 & 0.58 & 0.12 \\
1 fire 1981 & 21.57 & 20.56 & 1.64 & 0.32 & 0.15 \\
1 fire 1996 & 28.75 & 26.89 & 1.87 & 0.31 & 0.17 \\
2 fires 1981/96 & 27.07 & 25.60 & 1.88 & 0.33 & 0.16 \\
& $*$ & $*$ & $*$ & $*$ & $\mathrm{NS}$ \\
\hline
\end{tabular}

$\mathrm{NS}=$ not significant $*=\mathrm{p}<0.05$

\section{Table 3}

Mean values (standard error in parentheses) of $\mathrm{pH}$, electric conductivity (EC), \% $\mathrm{CaCO} 3, \%$ organic matter $(\mathrm{OM}), \%$ total $\mathrm{N}$, and available $\mathrm{P}$ in layer $2(5-10 \mathrm{~cm}$ depth) of the study soils.

\begin{tabular}{|c|c|c|c|c|c|c|}
\hline Fire frequency of soil samples & $\mathrm{pH} \mathrm{H} \mathrm{H}_{2} \mathrm{O}$ & E.C.dSm ${ }^{-11}$ & $\mathrm{CaCO}_{3} \%$ & O.M \%. & $\mathrm{N} \%$ & $\mathrm{P}_{\mathrm{mgkg}^{-1}}$ \\
\hline Control (no fire) & 8.02 & 0.152 & 21.28 & 4.28 & 0.18 & 4.14 \\
\hline 1 fire 1981 & 8.12 & 0.118 & 23.09 & 4.14 & 0.18 & 4.71 \\
\hline 1 fire 1996 & 8.02 & 0.140 & 24.94 & 5.56 & 0.16 & 4.92 \\
\hline \multirow[t]{2}{*}{2 fires 1981/96 } & 8.01 & 0.134 & 23.69 & 5.81 & 0.19 & 4.53 \\
\hline & NS & NS & NS & $*$ & NS & NS \\
\hline
\end{tabular}

$\mathrm{NS}=$ not significant $* \mathrm{p}<0.05$. 
Table 4

Mean values (standard error in parentheses) of cation exchange capacity (CEC), exchangeable $\mathrm{Ca}, \mathrm{Mg}, \mathrm{K}$ and $\mathrm{Na}\left(\mathrm{cmol} \mathrm{kg}^{-1}\right)$ in layer $2(5-10 \mathrm{~cm}$ depth) of the study soils.

\begin{tabular}{lccccc}
\hline Fire frequency of soil samples & CEC cmol kg-1 & $\mathrm{Ca} \mathrm{cmol} \mathrm{kg}^{-1}$ & $\mathrm{Mg} \mathrm{cmol} \mathrm{kg}^{-1}$ & $\mathrm{~K} \mathrm{cmol} \mathrm{kg}^{-1}$ & $\mathrm{Na} \mathrm{cmol} \mathrm{kg}^{-1}$ \\
\hline Control (no fire) & 20.45 & 19.08 & 0.40 & 0.47 & 0.18 \\
1 fire 1981 & 20.01 & 17.11 & 0.46 & 0.35 & 0.19 \\
1 fire 1996 & 26.08 & 20.49 & 0.75 & 0.34 & 0.19 \\
2 fires 1981/96 & 25.25 & 20.93 & 0.75 & 0.38 & 0.19 \\
& $\mathrm{NS}$ & $\mathrm{NS}$ & $*$ & $\mathrm{NS}$ & $\mathrm{NS}$ \\
\hline
\end{tabular}

$\mathrm{NS}=$ not significant $*=\mathrm{p}<0.05$

soil less able to soak up water and more prone to erosion.

There was no significant difference between the soil sites with regard to the content of $\mathrm{CaCO}_{3}$.

We observed a significant increase in organic matter content after fire. Litter and necromass accumulation during the post-fire phase increased soil organic matter in the surface horizon of the fire-affected soil (KNICKER \& al., 2005), and the values are below pre-fire levels in soils burned in 1981 (Table 1), probably because we observed different vegetation in this site. In layer 2 significant differences were observed, with the soils separating into two groups: soils with the highest organic matter content are the most recently burned (1996) and twice burned (1981 and 1996); and the other group comprises the control and the oldest burned (1981) soils. During the period a part of these nutrients has most likely been transferred down to the second layer, probably by translocation in the soil profile (IGLESIAS \& al., 1996, 1997; IGLESIAS, 2008).

Statistically significant differences appeared in layer 1 for $\mathrm{N}$ content between burned and unburned soils (Table 1), whereas $\mathrm{N}$ content in the 1981 burned soil has returned to pre-fire levels.

Available P content showed a significant increase in layer 1 (Table 2) after fire and also in twiceburned soil; this did not occur with layer 2 (Table 4). An increase in available P may be due to the combustion of organic $\mathrm{P}$ and to mineralisation occurring as a result of the high temperature reached during the fire (DEBANo \& al.,1986; KutIEL \& NAVEH, 1987b; Kutiel \& KutIEL, 1989; ÚBEDA \& al., 2004).

With regard to the cation exchange capacity, there was significant difference between soils for layer 1 and no significant difference between soils in layer 2. This was probably due to the fact that organic matter has not been totally mineralised, as a consequence of moderate burning intensity (IGLESIAS \& al., 1996, 1997; IGLESIAS, 2008; MURPHY \& al., 2006).

Increases in exchangeable $\mathrm{Ca}^{2+}$ were observed in layer 1 (Table 2), is consistent with the literature on Aleppo pine forests, such as KUTIEL \& NaveH (1987a,b), Kutiel \& InBAR (1993) and ULERY \& al. (1993).The increase in exchangeable cations as a consequence of the fires was more obvious shortly after the fires due to a release of Ca from plant material (IGLESIAS \& al., 1997).

With regard to exchangeable Mg we observed significant differences in layer 1 and layer 2 between burned and unburned soils (Tables 2 and 4 ), probably due to deposit from ash. For exchangeable $\mathrm{K}$, differences among concentrations in the soils and in layer 1 were statistically significant. Potassium increased after fire, but after the first growing season, subsequent $\mathrm{K}$ was obviously lost though leaching, or is strongly bound at more specific exchange sites (KUTIEL \& SHAvIV, 1990; LUDWING \& al., 1998).

\section{CONCLUSIONS}

The chemical changes in the soil are due to three processes: combustion of soil organic matter, input of ashes and alteration of nutrient availability (NEARY \& al., 1999; MURPHY \& al., 2006). In the present study the soil characteristics have not demonstrated significant differences between burned and unburned sites, and changes as a consequence of fire have which a small im- 
pact in the soil characteristics observed. The increases in elements lasted only a short time after the fire.

Nutrient-poor, Mediterranean-type ecosystems such as pine forests are characterised by the allocation of an important fraction of nutrients in low-turnover, surface organic pools, aboveground biomass and litter; a high proportion of these nutrients are only mobilised after a fire event which, directly or indirectly, turns them into mineral forms readily available for a new growth cycle (KuTIEL \& NAVEH, 1987b; MuRPHY \& al., 2006). Although fire destroys practically all the organic matter, the vegetation quickly regrows to a state similar to its previous one. The slight increase in soil nutrients after wildfire may contribute to the rapid regeneration and germination of the understorey plants. KUTIEL \& SHAVIV (1990) pointed out that the nutrients in soils are distributed in the form of a mosaic, which reflects the differences between the soil type and plant species and floral cover.

In spite of recurrent fires, the nutrient levels in the soils of the Aleppo pine forest remained practically the same and did not differ from the unburned soils. In the region, the soils of this type of community present a very high inertia, probably due to their long history: they have been cut and grazed several times, abandoned without any improvement, and then burned from time to time, leading to an impoverished state that present fires do not modify in any way.

\section{REFERENCES}

Certini, G. - 2005 - Effects of fire on properties of forest soils: A review - Oecologia 143 (1): 1-10.

DeBano, L.F., Perry, H. M. \& Overby, S. T. -1986- Effects of fuelwood harvesting and slash burning on biomass and nutrient relationships in a pynion-juniper stand. Pinyion-Juniper Conference - Reno, Nevada; January 13-16, pp. 382-386.

Dlapa, P., Simkovic, I., Doerr, S., Kanka, R., Mataix-Solera, J. -2008-Application of thermal analysis to elucidate water-repellency changes in heated soils - SSSAJ 72 (1): 1-10.

De Marco, A., Gentile, A.E., Arena, C. \& De Santo, A. 2004-Nutrient content and biological activity in burned and unburned soils of a Mediterranean maquis area of southern Italy - Geophys. Eur. Geosci. Un. Res. Abstracts, Vol 6, 06999.

De Marco, A., Gentile, A.E., Arena, C. \& De Santo, A. 2005- Organic matter, nutrient content and biological activity in burned and unburned soils of a Mediterranean maquis area of southern Italy.

Heras de las, J., Guerra, J. \& Herranz, J. M. -1995 - Influencia de la orientación y de la vegetación briofítica en la evolución de algunos parámetros edáficos 3-5 años después del fuego - Ecología 9: 109-119.

Iglesias, M. T., Cala, V., Walter, \& González , J. -1996Efectos de un incendio forestal en suelos de la Provincia de Madrid - Ecología 10: 155-161.

Iglesias, M. T., Cala, V., Walter, I. \& González, J. -1997— Evolución de parámetros edáficos en suelos bajo Pinus silvestris, Quercus pyrenaica y Quercus ilex después de un incendio forestal en suelos de la Comunidad de Madrid - Edafología 2: 233-240.

Iglesias, M.T. - 2008 - Estudio del carbono de la biomasa microbiana en suelos alterados — Lazaroa 29: 117-123.
Johnson, D.W., Murphy, J.F., Susfalk, R.B., Caldwell, T.G., Miller, W.W., Walker, R.F. \& Powers, R.F. - 2005The effects of wildfire, salvage logging, and post-fire $\mathrm{N}$-fixation on the nutrient budgets of a Sierran forest For. Ecol. Manag. 220: 155-165.

Knicker, H., González-Vila, F.J., Polvillo, O., González, J.A. \& Almendros, G. -2005- Fire-induced transformation of $\mathrm{C}$ and $\mathrm{N}$ forms in different organic soil fractions from a Dystric Cambisol under Mediterranean pine forest (Pinus pinaster) - Soil Biol. Bioch. 37: 701-718.

Kutiel, P., Naveh, Z. \& Kutiel, H. - 1990 - The effect of a wildfire on soil nutrients and vegetation in an Aleppo pine forest on mount Carmel, Israel. In: Goldamer, J.C \& Jenkins, M.J. (Eds.). Fire and Ecosystems Dynamics Mediterranean and Northern Dynamics - SPB Academic Publishing, the Hague.

Kutiel, P. \& Inbar, M. - 1993 - Fire impacts on soil nutrients and soil erosion in a Mediterranean pine forest plantation - Catena 20: 129-139.

Kutiel, P. \& Kutiel, H. -1989- Effects of a wildfire on soil nutrients and vegetation in an Aleppo pine forest, on mount Carmel, Israel - Pirineos 134: 59-74.

Kutiel, P. \& Naveh, Z. - 1987a - Soil properties beneath Pinus halepensis and Quercus calliprinos trees on burnt and unburnt mixed forest on Mt. Carmel, Israel - For. Ecol. Manag. 20: 11-24.

Kutiel, P. \& Naveh, Z . - 1987b - The effect of fire on nutrients in a pine forest soil — Plant and Soil 104: 269-274.

Kutiel, P. \& Shaviv, A. - 1989 - Changes of soil N-P status in laboratory simulated forest soil - Plant and Soil 120: 57-63.

Kutiel, P. \& Shaviv, A. - 1990 - Effects of soil types, plant composition and leaching processes on soil nutrients fo- 
llowing a simulated forest fire - In: Proceedings of International Conference of Forest Fire Research, 19-22 November, Coimbra, Portugal, pp. C.03.1-C.03.12.

Ludwig, B., Khanna, P. K., Raison, R. J. \& Jacobsen, K. L. -1998- Modelling cation composition of soil extracts under ashbeds following an intense slashfire in a eucalypt forest - For. Ecol. Manag. 103: 9-20.

Murphy, J.D., Johnson, D.W., Miller, W.W., Walker, R.F. \& Blank, R.R. - 2006- Prescribed fire effects o forest floor and soil nutrients in a sierra Nevada Forest - Soil Sci. 171 (3): 181-199.

Murphy, J.D., Johnson, D.W., Miller, W.W., Walker, R.F., Carroll, E.F. \& Blank, R.R. - 2006- Wildfire effects on soil nutrients and leaching in a Tahoe Basin watershed - J. Environ. Qual. 35: 479-489.

Neary, D. G., Klopatek, C. C., DeBano, L. F. \& Folliott, P. F. - 1999- Fire effects on belowground sustaina- bility: a review and synthesis - For. Ecol. Manag. 122: 51-71.

Úbeda, X., Lorca, M., Outeiro, L.R., Bernia, S \& Castelinou, M. - 2004- Effects of prescribed Fire on soil quality in Mediterranean grassland (Prades Mountains, north-east Spain) - Int. J. Wild. Fire 14(4): 379-384

Ulery, A.L., Graham, R.C. \& Armhein, C. - 1993- Woodash composition and soil $\mathrm{pH}$ following intense burningSoil Sci. 156: 358-364.

Ulery, A.L., Graham, R.C., Chadwick, O.A. \& Wood, H.B. - 1995-Decadescale changes of soil carbon, nitrogen exchangeable cations under chaparral and pine - Geoderma 65: 121-134.

Woodmansee, R. G. \& Wallach, L. S. - 1981 - Effects of fire regime on biogeochemical cycles. In: F.E. Clark and T. Roswall eds. Terrestrial nitrogen cycles. Stockholm - Ecol. Bull. 33: 649-669. 